\title{
ASPECTS OF ARABIC TEACHING AND LEARNING IN ELEMENTARY MADRASAH ON MINORITY MUSLIM INDONESIA
}

\author{
Ismail Suardi Wekke*, Ernawati*, Ujang Hudaya** \\ State Islamic College (STAIN) Sorong, West Papua \\ **State Islamic University of Sunan Gunung Djati, Bandung \\ Email: iswekke@gmail.com
}

Paper Presented in

The International Conference Arabic Language Education and Literature and Islamic Values between Expectation and Realization

Bandung, 11-12 November 2016

\begin{abstract}
This article would explore the practice of Arabic teaching and learning on minority muslim of Indonesia. There are three regions that allready explored, they are Papua, Minahasa, and Bali. Teachers are required to be actively using appropriate techniques and methods to stimulate students' interest in Arabic learning and teaching by emphasizing on aspects which are not different from other languages. In addition to language aspects, this writing is also presenting Arabic learning scopes which make Arabic learning easy to understand by the learners, especially by the beginners. Methods, techniques and media and approaches of the teachers play active role in learning process in the school, especially in Arabic learning where those all are supporting to achieve expected learning competencies. Arabic learning is inseparable from social and environmental scope around it. There is public role should be foundation and consideration continuously in the programming of learning system which will be implemented. Environmental condition becomes one of dimensions building the society. With inter-society meeting and building collaborations between them, social conflicts may be prevented. This formulation will be inseparable part within running classes. Psychological condition taken from outside into inside of the classes may contribute to cultivate the learning process. Finally, it is a proposal to enhance the material of teaching and learning in elementary school in adapting the condition of students. This material, besides using demonstration technique, a language is learned very light and easy to be understood, while the learning process is involving the learners to be actively using such method.
\end{abstract}

Keywords: teaching, Arabic, elementary, learning process

\section{INTRODUCTION}

Arabic language is Islamic World language which has a big contribution to worldlevel improvisation and competition. This is not only in linguistic aspect and linguistic science but furthermore, is also in the improvisation within methodological sector and learning techniques. This statement can be proven concretely and factually in the process of Arabic learning in where, recently, there are interactive-alternative learning techniques and models are emerging and motivating students' interest to learn Arabic language 
simultaneously and continuously. This context should be realized actively and creatively, to make the learning process run maximally and integrally (Gallagher, 2011; Taha-Thomure, 2008; Vassie, 2000).

In Arabic learning from the field of teaching, usually it is started from the lowest class by presenting scope of Arabic learning, from basic materials that is acceptable by children and easy to understand by introducing linguistic elements and activities where the students should know and understand them two formerly. That is in order to that the learners know the functions of the language itself. A language is not just involving a field of study but also as a centered factor in intellectual, social and emotional of the learners. Arabic mastery becomes an important requirement of the success of individual to answer the time challenges of globalization era. Formal Arabic learning in Islamic schools is the primary means for the learners to master Arabic language. This is intended to that the students can response proactively various developments of information, knowledge and technologies (Durugbo, 2014; McCarty, Zhao, \& Garland, 2007).

Through Arabic learning, students' communication skills can be developed both in spoken and written language to understand and deliver information, thoughts and feelings. Thus, Arabic lesson is needed to self-development of the students to grow and thrive as smart, skilled and Indonesian-personalized citizens and to develop knowledge, technology and culture, as well as to be ready to take part in national development (Elyas \& Picard, 2010). Arabic lesson is a lesson directed to encourage, coach, develop and guide students' ability and to grow their positive action on Arabic language both receptively and productively (Wekke \& Hamid, 2013). Receptive ability is an ability to understand other talks and writings. Whereas the productive one is an ability of using language as communication means both in spoken and written manners (Abdallah, 2010). Arabic ability and positive acts against Arabic language are very important to help understanding the sources of Islamic teachings 
are Quran, Hadith and Arabic books relating to Islam for the learners (Mohammed-Marzouk, 2012).

Moreover, Arabic language in elementary school is prepared to achieve linguistic basic competencies including four language skills taught integrally are listening, speaking, reading and writing skills. Arabic lesson is a lesson directed to encourage, coach, develop and guide students' ability and positive acts against Arabic receptively and productively. Receptive ability is ability to understand other's talks and understand writings. Whereas productive ability is ability to use language as communication means both in spoken and written language. Arabic language skills and positive acts against Arabic language are very important to help understanding Islamic teachings' sources are Quran, hadith and Arabic books regarding to Islam for learners (Agerström \& Rooth, 2009). In addition, muslim minority rely on the teaching of Quran when they started to learn the foundation of Islam.

Therefore, Arabic lesson in Islamic elementary school is prepared to achieve linguistic basic competencies including four linguistic skills which are taught integrally are listening, speaking, reading and writing skills. However, in elementary level, it is emphasized on listening and speaking skills as basis of linguistics, while in the intermediate education level, the four skills are taught in balance. Meanwhile in the advanced level, it is concentrated on skills of reading and writing, so that the learners are expected to be able accessing various references in Arabic language.

\section{ARABIC TEACHING AND LEARNING: ITS IMPLICATION ON CONTENT}

In Arabic learning, it is interested to study what had become a concept of Arabic learning though educational background just taught me religious education at general, since studens studied in public school. Books and journals that they read encouraged them to know and understand Arabic learning and entitle this writings by the Scope of Arabic Learning. 
Language is just a means. But in specific conditions it may be considered as political means. Meanwhile Arabic language has become part of religious lessons in Islam. Moreover, the choice of Arabic language development becomes compulsory and distinctive requirement. It is solely on the view of that the language skills should be an individual capacity of Muslim. So is the position of Islamic boarding school which always attempts to be part of people empowerment. Structured learning pattern which is run in program may encourage and motivate the students to get language skills. Therefore, road map is needed to develop such Arabic learning program. Arabic language as communication tool in Islamic religious activities, finally, considered as need, not solely as foreign language. This view leads Muslim to learn Quran letters since childhood before formal study in elementary school, to get the main foundation of Arabic learning. Absolutely this is related with Arabic learning. Since childhood, Muslim children have been introduced to this atmosphere. This is called linguistic awareness which leads to goodness. Like the characteristics of Arabic language have, Koran has also become a distinctive excellence entity. The Prophet Muhammad when the Koran was revealed in Arabic language was not the main reason of the use of Arabic language as Quran language (Wekke, 2015; Yusuf \& Wekke, 2015).

Since Arabic language became languages of Quran and Hadith, movements of understanding Arabic language have been emerged as parts of traditions to understand Islam (Wekke, 2015). The meaning of Koran is colored by the extent of understanding using Arabic language approach (Wekke \& Lubis, 2008). This can be done if an individual has formulated such meaning using linguistics awareness since the beginning. However, the education running is always emphasizing Arabic language on its scientific status per se, not as means for understanding Islam (Al-Rajhi, Bartlett, \& Altman, 2013). Arabic learning has been positioned as main activity. But to form a learning atmosphere and simultaneously chances for the learners to master language skills become distinctive challenges. Mastering Arabic 
lesson will be a foundation to master other lessons. Arabic lesson is a supporting factor to determine Islamic rulings in fiqh lesson. Simultaneously, Arabic language will lead the students have ability to identify their capability of studying Islam more widely, not limited to merely language proficiency. This position of Arabic language becomes a distinctive reason to continuously attempt renewals to get processes which can achieve goals of learning in a better manner. It is like the practice of Arabic learning in Islamic boarding schools. A research about the desire to willingness Arabic language said that there are, at least, three things are related to this problem of learning (Dean, 2014). Firstly, the widespread practice of using I'rab which lets the beginners to face difficulties. Whereas the mastery of Arabic language is not merely measured by the skill of analyzing words in sentences using I'rab tools. By I'rab, when we are going deep into Arabic language, actually we are not studying to use Arabic language, but it is about the language itself. Secondly, discussion about nahwu is very detailed. With a consideration to the effectiveness and efficiency, such material is not supporting the language learning process. Unless when it is used to go deep into Arabic language in specific reviews like in department of language and letter. But for students who are targeted to go deep into religious knowledge, it is a less proper choice to study Arabic language with its detailed aspects of nahwu in the beginning level it will be overlapped. Finally, textbooks used, all of them are products of Mid-east area. This means that language used in the books is devoted to Arabic speakers as their mother language, not as second language. Thus, it will ignore the existence of the different of language's socio-linguistics contexts in mid-eastern culture and Indonesian culture. Material relevancies in the books become a problem which makes gaps between discussions in the lessons and the real facts experienced in daily life. As a response to those three problems, Islamic boarding school education introduces a modern term to be alternation of traditional learning. Using communicative approach, it is taken as innovation to improve the existing Arabic learning 
process. Meanwhile the emergence of tendencies of making Islamic review as means to solely implement concepts without going deep into the scholars views contained in heritage books becomes required (Inayatullah \& Milojević, 2014; Niyozov \& Memon, 2011).

In Arabic learning, learning system and principles are very urgent for the teacher to realize the learning process in question since each language has elements and skills which can be seen separately and integrally, so that there are paradigm and phenomenon formatted and called language. Language skills and performances are also varied in the forms of spoken and written language, even there are receptive skills (listening and reading) and there are productive skills (speaking and writing). This system is called integrated/separated system.

\section{ASPECTS OF ARABIC TEACHING AND LEARNING}

Daily real facts show that people are more doing speaking and listening. This is reasonable since their initial lingual activities are listening and speaking as spoken language. Speaking skill is ability to pronounce articulation voices or words to state, express and deliver thought, idea and feelings. The listeners accept information through series of tones, sound pressures and joints determination when they are doing direct communication (face to face) and also speaker's hand gestures and facial expression. Speaking skill is productive skill which is integrated. 'Productive' means that when speaking, people use spoken language to deliver talks about their thoughts, ideas and feelings. 'Integrated' means in the talks, there are combination of number of skills to be components of talks, mastery of talks, mastery of techniques and language performance. Speaking skills should be trained for students through process of learning and practices continuously and systematically to accelerate the students in communication.

There are two activities done alternately by individuals in their communication: being communicator and being communicant. In an effective communication, a rapid changing 
process from being communicator to being communicant or vice versa is considered an ordinary and usual event. There are two kinds of public speaking based on environmental scopes: Formal Scope, that is, official scope which has particular formality and properness. In this scope, there are relatively more stringent rules relating to clothes, situation, topics, vocabs and speaking style which should be adjusted to the formal scope. For example: peroration. The second scope is Non-formal Scope, that is, a scope which contains more looseness in speaking where the situation is more familiar, the speaking style is free, the clothes is unregulated, and so do speaking style and its format. For example: lecture.

The Implementation of Direct Method to Enhance Students' Speaking Skill in

\section{Conversation Section of Arabic Learning in Public/Islamic Elementary Schools}

The implementation of direct method in learning and teaching activities in Arabic learning, especially in conversation section begins from a view of that the most important thing in language learning is speaking skill. To make it realized in every individual in language learning process, especially in Arabic learning, teachers should be used to use Arabic language in their interactions and as intermediate language in learning and teaching activities, so that the students will be used to use Arabic language. (El Zahra Fatimah, 2004, p. 9)

According to Arabic learning competency standards for Public/Islamic

Elementary School, speaking competency (expressing information orally in the forms of explanation or dialog about human body parts/a'dhooul insaan) is a basic competency to express information orally using simple sentences about human body parts/a'dhooul insaan. Based on these Competency Standards and Basic Competencies, goals of Arabic learning for this speaking competency can be formulated, that is, students can perform conversation or dialog about human body parts/a'dhooul insaan. 


\section{The Scope of Arabic Learning}

Arabic language skills and positive attitude against Arabic language are considered very important to help learners to understand the sources of Islamic teachings are Koran, Hadith and Islamic Books written in Arabic language. We can also see that the scopes of Arabic lesson, based on regulation of the Minister of Religion, are directed to topics such as, (1) in the level of Islamic Elementary School: introduction, stationeries, vocations, family, human body parts, in the house, in the garden, in the school, in the laboratory, in the library, in the canteen, hours, daily activities and recreation; (2) in the level of Islamic Junior High School: self-concept, school life, family life, house, hobbies, profession, religious activities and environment; (3) in the level of Islamic Senior High School: introduction, family life, hobbies, vocations, teens, health, public facilities, tourism, Islamic stories, Islamic insights, Islamic celebration days, Islamic figures; (4) in the level of Islamic Senior High School, program of language: self-concept, school life, family life, daily life, hobbies, tourism, public services and vocations; (5) in the level of Islamic Senior High School, religious program: alKoran al-Kareem, religious life, noble character, teaching activities, knowledge, trading, recreation, world of Arab, Arabian people and language (Elzahra Fatimah,2014, p.3).

Success achievement of Arabic language skills is signed by some skills are as follows:

first, listening skill (istima'). Listening skill can be achieved by practices by listening differences of phonemes and differences of phrases both directly from native speaker and tape recorder. To understand forms and meanings of spoken words needs practices by listening recorded materials and, simultaneously, watching series of pictures reflecting the meanings. Second, Speaking skill (kalam). Speaking skill is considered the most complicated linguistic skill since it is relating to the matter of thinking or thinking what should be said and at the same time saying what is being thought. These all needs stocks of words and sentences which are appropriate for expected situations and needs more practices to pronounce and 
express or state thoughts and feelings orally, as well as using lexical, grammatical and semantic systems simultaneously in specific intonation. Third, Reading skill (qira'ah). This skill includes two are recognizing written symbols and understanding their meanings through some ways such as, among others, providing children with sufficient vocabularies. Reading activity provides language input which is equal with listening activity. However, reading has excellences over listening in term of giving more accurate linguistic items. Besides, a good reader has autonomic property and may build interaction with Arabic magazines, books or newspaper. This way of learning may provide more vocabularies. Fourth, Writing skill (kitabah). Writing skill involves three things are: (1) Skill of making alphabet, that is, express different sounds from other languages. (2) Skill of spelling, which will be developed to be sentences modification, that is, modifying available sentences with other elements, completing unfinished sentences or changing active sentences to be passive sentences, or vise versa. (3) Skill of expressing feelings and thoughts though writings or usually called composition. This skill can be achieved through practices as follows: (a) Summarizing selected text and retelling it in written form using the students' self-vocabularies. (b) Telling viewed objects or students' daily activities. (c) Describing an object or event in detail. (d) (4) Telling things usually done by the students like riding bicycle and etc.

Arabic learning process using these communicative teaching materials is done as it is without any artificial thing, so that the learning process is meaningful without verbalism aspect of language learning which is difficult to be understood by the learners. Usually, for lower class students, the scope of Arabic learning is started by conversation about introduction using light and easy Arabic language to be understood by the learners like 'What is your name?' while another answers 'My name is Ainun', and so forth. Practicing conversation will make the learners who initially have less fond of Arabic learning to find that it becomes interesting and makes them continue to learn. 


\section{CONCLUSION}

Arabic learning is inseparable from its social and environmental scopes since Arabic language is not just a foreign language but also a language needed for, mainly, understanding Koran and Hadith as Muslim's life guidance. Understanding them two needs Arabic learning first. Arabic learning tends to be less fun for its learners and even is considered as boring learning. They consider that Arabic learning is only consisting of Arabic letters that are difficult to understand, moreover for those who did not recognize hijaiyyah letters from their early ages. Initially it was difficult to make the children be interested in learning Arabic since in their minds, Arabic learning is closely related with memorizing Arabic letters and memorizing Quranic verses, so that, they have been reluctant to follow Arabic lesson before being introduced to it, let alone those who have not been taught how to write Arabic letters and to understand Arabic texts in their environment.

\section{REFERENCE}

Abdallah, S. (2010). Islamic ethics: an exposition for resolving ICT ethical dilemmas. Journal of Information, Communication and Ethics in Society, 8(3), 289-301.

Agerström, J., \& Rooth, D.-O. (2009). Implicit prejudice and ethnic minorities: ArabMuslims in Sweden. International Journal of Manpower, 30(1/2), 43-55.

Al-Rajhi, I., Bartlett, D., \& Altman, Y. (2013). Research note: the development of an Arabic cross-cultural adjustment scale. Cross Cultural Management: An International Journal, 20(3), 449-463.

Dean, J. (2014). Muslim values and market value: a sociological perspective. Journal of Islamic Marketing, 5(November 2012), 20-32.

Durugbo, C. (2014). Managing information for collaborative networks. Industrial Management \& Data Systems, 114(8), 1207-1228.

Elyas, T., \& Picard, M. (2010). Saudi Arabian educational history: impacts on English language teaching. Education, Business and Society: Contemporary Middle Eastern Issues, 3, 136-145.

Gallagher, K. (2011). Bilingual education in the UAE: factors, variables and critical questions. Education, Business and Society: Contemporary Middle Eastern Issues, 4(1), 62-79.

Inayatullah, S., \& Milojević, I. (2014). Augmented reality, the Murabbi and the democratization of higher education: alternative futures of higher education in Malaysia. On the Horizon, 22(2), 110-126. 
McCarty, W. P., Zhao, J., \& Garland, B. E. (2007). Policing : An International Journal of Police Strategies \& Management Article information: Occupational Stress and Burnout between Male and Female Police Officers: Are There Any Gender Differences?, 30(4), 672-691.

Mohammed-Marzouk, M. R. (2012). Teaching and Learning in Iraq: A Brief History. The Educational Forum, 76(2), 259-264.

Niyozov, S., \& Memon, N. (2011). Islamic Education and Islamization: Evolution of Themes, Continuities and New Directions. Journal of Muslim Minority Affairs, 31(1), 5-30.

Taha-Thomure, H. (2008). The status of Arabic language teaching today. Education, Business and Society: Contemporary Middle Eastern Issues, 1(3), 186-192.

Vassie, R. (2000). Improving access in bilingual, biscript catalogues through Arabised authority control. Online Information Review, 24(6), 420-429.

Wekke, I. S. (2015). Arabic Teaching and Learning: A Model From Indonesian Muslim Minority. Procedia - Social and Behavioral Sciences, 191, 286-290.

Wekke, I. S. (2015). Tradisi pesantren dalam konstruksi kurikulum bahasa Arab di lembaga pendidikan minoritas muslim Papua Barat. KARSA: Jurnal Sosial dan Budaya Keislaman, 22(1), 20-38.

Wekke, I. S., \& Hamid, S. (2013). Technology on language teaching and learning: a research on Indonesian pesantren. Procedia-Social and Behavioral Sciences, 83, 585-589.

Wekke, I. S., \& Lubis, M. A. (2008). A Multicultural approach in Arabic language teaching: creating equality at Indonesian pesantren classroom life. Sosiohumanika, 1(2).

Yusuf, M., \& Wekke, I. S. (2015). Active Learning on Teaching Arabic for Special Purpose in Indonesian Pesantren. Procedia - Social and Behavioral Sciences, 191, 137-141. 